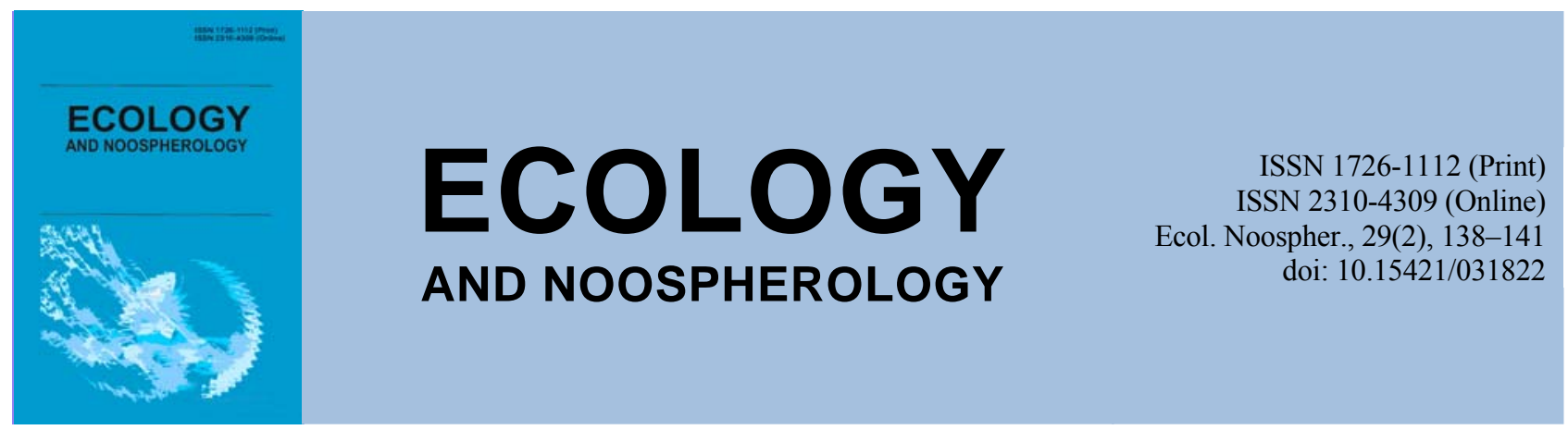

\title{
Influence of modeled microgravity on tobacco mosaic virus
}

\author{
N. P. Sus*, A. V. Orlovskyi*, O. A. Boyko**, V. O. Tsvigun*, A. L. Boyko* \\ *Institute of Agroecology and Environmental Management of NAAS, Kyiv, Ukraine \\ **National University of Life and Environmental Sciences of Ukraine, Kyiv, Ukraine
}

Article info

Received 17.11.2018

Received in revised form 23.11.2018

Accepted 28.11.2018

Institute of Agroecology and Environmental Management of NAAS, Metrolohichna Str., 12, Kyiv, 03143, Ukraine.

Tel.: +38-099-158-64-61

E-mail: nazar.sus@gmail.com

National University of Life and Environmental Sciences of Ukraine, Heroiv Oborony Str., 13 Kyiv, 03041, Ukraine.
Sus, N. P., Orlovskyi, A. V., Boyko, O. A., Tsvigun, V. O., \& Boyko A. L. (2018). Influence of modeled microgravity on tobacco mosaic virus. Ecology and Noospherology, 29(2), $138-141$. doi:10.15421/031822

Clinorotation is an effective method of treating diseases caused by some plant viruses. Therefore, we researched the influence of microgravity (modeled by clinorotation) on a tobacco mosaic virus (TMV) that infects many agricultural crops. It is known that cells of plants (infected with TMV) contain viral inclusion bodies or viroplasms and amount of viral inclusion bodies correlates with harmfulness of TMV. Therefore, the purpose of this study was to find out the effect of influence of modeled microgravity on inclusion bodies of TMV. In this study, we cultivated Nicotiana tabacum L. and inoculated them with TMV that was isolated from Norway maple (Acer platanoides L.). Then we divided these plants into two groups and cultivated these plants under normal and microgravitation conditions. Microgravity conditions were modeled by clinorotation at 2 rpm for 4 hours a day. This experiment lasted 36 days. Changes of the amount of TMV inclusion bodies in cells of plants that cultivated under normal and microgravitation conditions was investigated by luminescence microscopy. We found that formation of TMV inclusion bodies under microgravitation conditions is first slowed down compared to formation under normal conditions and then their amount quickly decreasing. These results demonstrate the gravisensitivity of TMV. It was suggested hypothesis that this viroplasm pattern caused by the disorganization of cortical microtubule-associated ER sites (C-MERS) that are nodes of cellular transport pathways and nucleation centers of cortical microtubules and cortical microfilaments. It is known that under microgravity conditions there is a disorganization and disorientation of cortical microtubules, which stabilize C-MERS on which TMV viroplasms are formed. Thus, the disorganization and disorientation of cortical microtubules probably causes the disorganization of C-MERS, which leads to a decrease in the number of TMV viroplasms under the influence of microgravity. In this context, it is worth noting that some plant viruses, such as a Wheat streak mosaic virus (WSMV), a Potato virus $M(P V M)$ and Potato curly dwarf virus (PCDV), are gravisensitive. These viruses belong to different taxa, for example $W S M V$ belong to genus Tritimovirus (family Potyviridae), PVM belong to genus Carlavirus (family Betaflexiviridae) and $P C D V$ belong to plant rhabdoviruses (uncertain taxonomic position), and differ both structurally and functionally. Therefore, the gravisensitivity of these viruses can occur by other mechanisms. Thus, antiviral therapeutic effect of clinorotation based on gravisensitivity of TMV and can be used in the production of virus-free seeds. To confirm this hypothesis, it is necessary to conduct a systematic review, as well as experimentally establish the fact of the disorganization of the C-MERS under microgravity conditions.

Keywords: TMV (tobacco mosaic virus); clinorotation; microgravity; inclusion bodies; viroplasm; gravisensitivity; cortical MT-associated ER sites

\section{Вплив модельованої мікрогравітації на вірус тютюнової мозаїки}

\author{
Н. П. Сус*, А. В. Орловський*, О. А. Бойко**, В. О. Цвігун*, А. Л. Бойко* \\ *Iнститут агроекології і природокористування НААН, Київ, Україна \\ **Національний університет біоресурсів і природокористування Украӥни, Київ, Украӥна
}

Виявлено, що утворення внутрішньоклітинних включень ВТМ (вірусу тютюнової мозаїки) в умовах мікрогравітації (моделюється кліностатуванням) спочатку сповільнюється в порівнянні з утворенням в нормальних умовах, а потім їх 
кількість швидко зменшується. Ці результати демонструють гравічутливість ВТМ. Відомо, що в мікрогравітаційних умовах спостерігається дезорганізація та дезорієнтація кортикальних мікротрубочок, що стабілізують кортикальні мікротрубочкоасоційовані ЕПР-сайти (К-МЕПРС), на яких формуються віроплазми ВТМ. Таким чином, дезорганізація та дезорієнтація кортикальних мікротрубочок, імовірно, спричинює дезорганізацію К-МЕПРС, що обумовлює зменшення кількості віроплазм ВТМ під впливом мікрогравітації. Отже, антивірусний терапевтичний ефект кліностатування базується на гравічутливості ВТМ і може бути використаний при отриманні безвірусного садивного матеріалу. Для підтвердження даної гіпотези необхідно провести метааналіз, а також екпериментально встановити факт дезорганізації К-МЕПРС в умовах мікрогравітації.

Ключові слова: вірус тютюнової мозаїки; кліностатування; мікрогравітація; внутрішньоклітинні включення; віроплазма; гравічутливість; кортикальні мікротрубочко-асоційовані ЕПР-сайти

\section{Вступ}

Нині кліностатування є одним із найбільш перспективних підходів етіотропної антифітовірусної терапії. Зокрема, установлено, що в умовах мікрогравітації (змодельованої методом кліностатування), спостерігається значне зменшення титру віріонів щонайменше трьох вірусів, а саме вірусу смугастої мозаїки пшениці, або ВCMП (Wheat streak mosaic virus, WSMV) (Mishchenko et al., 1999; Boyko, 2003), М-вірусу картоплі, або МВК (Potato virus M, PVM) (Danilova et al., 2014), вipycy кучерявої карликовості картоплі, або ВККК (Potato curly dwarf virus, PCDV) (Didenko et al., 1999). Таким чином, кліностатування може використовуватися як спосіб отримання безвірусного посадкового матеріалу.

У клітинах рослин, що інфіковані вірусом тютюнової мозаїки, або ВТМ (Tobacco mosaic virus, TMV), формуються структури, що називаються віроплазмами (внутрішньоклітинними включеннями, тілами включення, Х-тілами, вірусними реплікаційними комплексами), кількість яких, як правило, позитивно корелює 3 рівнем хвороби (Liu and Nelson, 2013). Згідно 3 літературними даними віроплазми ВТМ формуються на кортикальних мікротрубочко-асоційованих ЕПР-сайтах, або К-МЕПРС (C-MERS), де відбувається рекрутування мембран і білків хазяїна, які їм необхідні для реплікації і транспорту, а також для доставки вірусних білків руху (БР), віріонів до плазмодесм (Реña and Heinlein, 2013; Heinlein, 2016; Griffing et al., 2016). У цих сайтах сходяться кортикальні мікротрубочки (КМТ), кортикальний ендоплазматичний ретикулум, або ЕПР (ER), та кортикальні мікрофіламенти (Peña and Heinlein, 2013; Heinlein, 2016). Таким чином, К-МЕПРС є стабільними (не динамічними) транспортними вузлами, в яких зустрічаються як мікротрубочковий цитоскелет, так і ЕПР-мікрофіламентна мережа, вздовж якої, як відомо, за домомогою міозину XI-K F-актинопосередковано пересуваються різні органели (тіла Голджі, пероксисоми, мітохондрії) та зупиняються на К-МЕПРС. Стабільність цих вузлів насамперед забезпечується кортикальними мікротрубочками, або мікрофіламенти, як i ЕПР, $є$ досить динамічними структурами (Peña and Heinlein, 2013; Heinlein, 2016; Ueda et al., 2010). Таким чином, віроплазми є маркером ВТМінфекції, а їх кількість $є$ показником ступеня інфекційного процесу. Тому метою нашого дослідження було з'ясувати особливості впливу модельованої мікрогравітації на віроплазми ВТМ.

\section{Матеріали та методи досліджень}

У даному дослідженні як модель ВТМ нами було використано ізолят вірусу тютюнової мозаїки, виділений $з$ клена гостролистого (Acer platanoides L.) (BTM (К)). Патогенетичний процес, що спричинюється даним ізолятом в рослини-хазяїна (A. platanoides) та рослиніндикаторів, був нами попередньо описаний (Orlovskyi et al., 2016). Для дослідження гравічутливості ВТМ (К) використовували рослини тютюну Nicotiana tabacum L. сорту «Гавана», що були вирощені в стерильних умовах.
Механічну інокуляцію рослин $N$. tabacum проводили очищеними та сконцентрованими препаратами ВТМ (К).

Дослід складався 3 двох варіантів. У першому варіанті досліду інфіковані рослини вирощували в умовах мікрогравітації, що моделювалася горизонтальним кліностатуванням, за якого вісь росту рослини розміщена горизонтально й збігається з віссю обертання контейнерів. Процес кліностатування тривав 4 години (3 частотою обертання 2,0 rmp) й повторювався протягом 36 діб. Для другого варіанта - рослини вирощували в стаціонарних умовах (контрольний варіант). Рослини обох варіантів вирощували при температурі $+19-+23{ }^{\circ} \mathrm{C}$, освітленості 8-10 тис. лк.

Для виявлення та фіксації віроплазм ВТМ нами готувалися зразки 3 рослин обох варіантів досліду та використовувався метод люмінесцентної мікроскопії. Фарбування препаратів здійснювали барвником акридиновим оранжевим (Boyko, 2003).

\section{Результати та їх обговорення}

Нами було встановлено, що кількість внутрішньоклітинних включень ВТМ у клітинах рослин, що вирощувалися в умовах мікрогравітації, у порівнянні 3 кількістю віроплазм у клітинах рослин, що вирощувалися в стаціонарних умовах, значно менша. Варто також зазначити, що спершу кількість віроплазм ВТМ у клітинах рослин, що росли в умовах модельованої мікрогравітації, збільшувалася, хоча завжди була меншою, ніж у клітинах рослин, що вирощувалися в стаціонарних умовах. Однак починаючи 3 20-24-го дня після початку інфекції спостерігається поступове зменшення внутрішньоклітинних включень (рис. 1).

Окрім даних дослідів нами було виявлено, що ВТМконтамінованими є соняшник (Helianthus annuиs L.), хміль (Humulus lupulus L.) та печериця (Agaricus bisporus (J.E.Lange) Imbach) (останній ізолят переноситься равликом Helix pomatia L. (Boyko et al., 2014)). Ці ізоляти $\epsilon$ серологічно спорідненими з ВТМ(К) (Boiko et al., 1992) й під впливом мікрогравітації у вищезазначених природних хазяїв спостерігалося зникнення симптомів, що викликали ці ізоляти. Проте дані явища не вивчалися нами на клітинному рівні й потребують подальших досліджень.

Таким чином, віроплазмам ВТМ властива гравічутливість (чутливість до гравітаційного абіотичного фактора). «Гравічутливість» віруса, на відміну від «гравітропізму», за аналогією 3 клітинними формами життя є ознакою, яка визначає залежність життєвого циклу віруса від нормальних гравітаційних умов, а не реагування на гравітаційний абіотичний фактор як на подразник (Korduum, 2009). Слід зазначити, що ВТМ, як і інші віруси, проявляе ознаки життя лише в клітині й віроплазми можна вважати стадією його розвитку. Заразом, згідно 3 літературними даними, віріонам ВККК, наприклад в умовах in vitro, гравічутливість не властива, проте проявляється в умовах in vivo. Оскільки для ВТМ(К) у даному дослідженні середовищем першого порядку була сукупність умов у рослинах $N$. tabacum, то середовище другого порядку, тобто мікрогравітаційні умови, впливали, імовірно, на ВТМ(К) опосередковано й чинили 


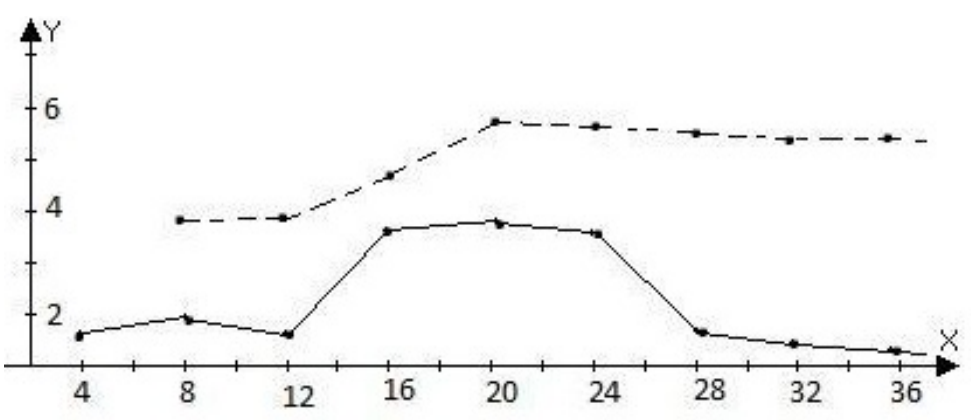

Рис. 1. Залежність кількості віроплазм у клітині

від умов вирощування рослин $N$. tabacum, що інфіковані ВТМ (К)

(Y - середня кількість включень із десяти клітин;

$\mathrm{X}$ - кількість діб; --- - вирощування рослин у стаціонарних умовах;

- - вирощування рослин у мікрогравітаційних умовах).

безпосередній вплив на рослину-хазяїна. Таким чином, явище пролонгованого впливу мікрогравітації на внутрішньоклітинні включення пояснюється здатністю рослини-хазяїна адаптуватися до цього абіотичного фактора, тому зміни в клітинах $N$. tabacum виникали поступово й при досягненні певного порогового значення зумовили запізніле зменшення кількості віроплазм ВТМ (К).

3 огляду на патерн змін чисельності віроплазм, що спостерігався нами в цьому дослідженні, ми вважаємо, що основною мішенню впливу мікрогравітації, що $є$ тригером, який запускає певні зміни у функціонуванні клітинихазяїна, які спричиняють сповільнення формування віроплазм ВТМ та їх подальше реформування, $\epsilon$ дезорганізація кортикальних мікротрубочко-асоційованих ЕПР-сайтів (C-MERS).

Водночас відомо, що процес самоорганізації мікротрубочок $є$ гравітаційно-залежним. Зокрема, відомо, що в клітинах головного корення шестидобових паростків Brassica rapa L., вирощених в умовах модельованої мікрогравітації (здійснювалося горизонтальне кліностатування протягом 6 діб $з$ частотою обертання $2 \mathrm{rpm})$, КМТ були переривчастими та розміщувалися хаотично в порівнянні 3 суцільними, паралельно розміщеними й орієнтованими залежно від вектора гравітації КМТ клітин головного кореня паростків, що були вирощені в стаціонарних умовах (Kalinina, 2006). Ці дані були підтверджені також дослідженнями на зародкових коренях Arabidopsis thaliana GFP-MAP4 (Bulavin, 2015). В умовах модельованої гіпергравітації виявлено переорієнтацію КМТ й у клітинах надземних органів рослин, наприклад епікотилів Vigna angularis (Willd.) Ohwi et Ohashi (Soga et al., 2006).

Щодо мікрофіламентної (МФ) складової цитоскелету, то варто зазначити, що в умовах мікрогравітації вона здебільшого не зазнає істотних змін в орієнтації (Shevchenko and Kordyum, 2012.). У клітинному кортексі рослин мікрофіламентна та мікротрубочкова складові цитоскелету взаємодіють за посередництва деяких формінів Іе групи. Наприклад, AtFH14 сильніше взаємодіє 3 мікротрубочками, ніж 3 мікрофіламентами. Слід також зазначити, що після розбирання кортикальних актинових філаментів вони специфічно відновлюються вздовж кортикальних мікротрубочок і що відновлення масиву актинових філаментів залежить від інтактного масиву мікротрубочок. Окрім AtFH14 до зв'язування мікротрубочок та мікрофіламентів залучені OsFH5 та AtFH4 (Van Gisbergen and Bezanilla, 2013). На відміну від тваринних клітин, у клітинах вищих рослин центросома не є центром організації мікротрубочок (ЦОМТ). Нуклеація кортикальних мікротрубочок відбувається в різних ЦОМТ, що розсіяні по клітинному кортексі та нуклеюють 3 інших мікротрубочок. Вважається, що К-МЕПРС виконують також роль ЦОМТ для кортикальних мікротрубочок (Heinlein, 2016). 3 іншого боку, форміни є нуклеаторами актинових філаментів (Van Gisbergen and Bezanilla, 2013). Таким чином, К-МЕПРС також відбувається нуклеація як кортикальних мікротрубочок, так i кортикальних мікрофіламентів, проте нуклеація актинових філаментів може відбуватися й з інших сайтів за посередництва інших формінів (Van Gisbergen and Bezanilla, 2013). Отже, у разі дезорганізації К-МЕПРС під впливом мікрогравітації нуклеація мікрофіламентів може відбуватися 3 інших сайтів.

Було продемонстровано збільшення кількості ЕПРтілець в умовах мікрогравітації, похідних гранулярного ендоплазматичного ретикулуму (гЕПР), у статоцитах та клітинах дистальної зони розтягу коренів проростків Arabidopsis thaliana (L.) Неynh. Ступінь цих змін кількості ЕПР-тілець корелював 3 тривалістю кліностатування. Гетерогенність цих ЕПР-тілець також збільшувалася 3 тривалістю кліностатування (Romanchuk, 2010). Даний патерн може свідчити про наявність порушень К-МЕПРС, які $\epsilon$ частиною транспортного шляху ЕПР-тілець (Реña and Heinlein, 2013; Heinlein, 2016).

Таким чином, в умовах мікрогравітації, імовірно, відбувається дезорганізація К-МЕПРС, що спричинюється насамперед змінами в мікротрубочковому цитоскелеті, який, як відомо, зумовлюе статичність К-МЕПРС. Оскільки наявність К-МЕПРС є обов'язковою умовою як для ВТМ-інфекції, так і для інших вірусів (обгрунтування даної тези тут: Реña and Heinlein, 2013; Heinlein, 2016; Griffing et al., 2016), то дезорганізація К-МЕПРС унеможливлює подальшу ВТМ-інфекцію. Явище поступового зменшення віроплазм залишається незрозумілим та може бути спричиненим як адаптацією рослини-хазяїна до мікрогравітаційних умов, що зумовлювала пролонговану відповідь, так i власне віроплазмами, які, як відомо, також стабілізують К-МЕПРС (Heinlein, 2016). Отож, для підтвердження цієї гіпотези необхідно провести метааналіз, а також екпериментально встановити факт дезорганізації К-МЕПРС в умовах мікрогравітації.

\section{Висновки}

Отже, виявлена нами закономірність зменшення внутрішньоклітинних включень під впливом модельованої мікрогравітації свідчить, що вірусу тютюнової мозаїки властива гравічутливість. Ця властивість може бути використана як мішень для направленої ВТМ-терапії та отримання здорового посадкового матеріалу. Механізм впливу мікрогравітації на ВТМ, імовірно, включає дезорганізацію кортикальних мікротрубочко-асоційованих ЕПР-сайтів насамперед внаслідок дезорганізації та дезорієнтації кортикальних мікротрубочок, проте для підтвердження цієї гіпотези необхідно провести метааналіз, а також екпериментально встановити факт дезорганізації К-МЕПРС в умовах мікрогравітації. 


\section{References}

Boyko, A. L. (2003). Osnovy ekolohii ta biofizyky virusiv [Fundamentals of ecology and biophysics of viruses]. Fitosotsiotsentr, Kyiv (in Ukrainian).

Boiko, O. A., Taranenko, P. K., Bukhalo, A. S. (1992). Virusnaya bolezn shampinona pri intensivnoy tekhnologii ego vyrashchivaniya [Viral disease of agaric under intensive cultivation technology]. Dokl. AN Ukrainy, 8, 159-160 (in Russian).

Boyko, O., Shevchenko, T., Lukashov, D., Orlovska, G. (2014). The Circulation of Phytovirus among Plants and Fungy Involving the Helix Pomatia L. Problemy. Bulletin of Kyiv National Taras Shevchenko University, 17, 69-71.

Bulavin, I. V. (2015). Hravichutlyvist koreniv, utvorenykh z lystkovykh eksplantiv Arabidopsis thaliana $\mathrm{v}$ kulturi in vitro [Gravisensitivity of roots of Arabidopsis thaliana formed in vitro from leaf explants]. The Bulletin of Kharkiv National Agrarian University. Series Biology, 1, 6-13 (in Ukrainian).

Danilova, O. I. (2014). Doslidzhennia nespetsyfichnoi stiikosti roslyn pomidora do $\mathrm{M}$ - ta $\mathrm{Y}$-virusiv kartopli [Investigation of nonspecific resistance of tomato plants to Potato virus $\mathrm{M}$ and Potato virus Y]. Naukovi dopovidi Natsionalnoho universytetu bioresursiv i pryrodokorystuvannia Ukrainy, 6, 1-11 (in Ukrainian).

Didenko, L. F., Parkhomenko, N. I., Maksimenko, L. A., Dyachenko, N. S., Zaritskiy, N. M., Kozar, F. E. (1999). Vlyianye klynostatyrovanyia na vyrus kurchavoi karlykovosty kartofelia in vitro y in vivo [Influence of clinostating on the curly potato dwarf virus in vitro and in vivo]. Kosm. nauka tehnol., 5, 118-122 (in Russian).

Griffing, L. R., Lin, C., Perico, C., White, R. R., Sparkes, I. (2016). Plant ER geometry and dynamics: biophysical and cytoskeletal control during growth and biotic response. Protoplasma, 254, 43-56.

Heinlein, M. (2016). Viral Transport and Interaction with the Host Cytoskeleton. In: Kleinow $\mathrm{T}$, ed. Plant-virus interactions: molecular biology, intra- and intercellular transport. Springer International Publishing, Switzerland, 39-67.

Kalinina, I. M. (2006). Mikrotrubochky v klitynakh epidermisu ta kory korenia Brassica rapa za umov klinostatuvannia [Microtubules in epidermal and cortical root cells of Brassica rapa under clinorotation]. Tsitol Genet., 40, 21-27 (in Ukrainian).

Korduum, E. L. (2009). Microgravity conditions experimental basis used for the investigation of a gravity role in the plants' ontogenesis process. Ecology and Noospherology, 20, 20-23.

Liu, C., Nelson, R. S. (2013). The cell biology of Tobacco mosaic virus replication and movement. Frontiers in Plant Science, 4, 1-10.

Mishchenko, L. T., Boyko, A. L., Chernyuk, S. O. (1999). Vplyv klinostatuvannia na pokaznyky serolohichnoho analizu virusu smuhastoi mozaiky pshenytsi $\mathrm{v}$ roslynakh Triticum aestivum [The influence of microgravitation on characteristics of viruses of striped mosaic wheat in Triticum aestivum]. Biopolym. Cell., 15, 319-323 (in Ukrainian).

Orlovskyi, A., Moroz, V., Boiko, A. (2016). Skryninh ta biolohichni vlastyvosti izoliativ VTM (Tobamovirus) na roslynakh platana skhidnoho (Platanus orientalis L.) ta klena hostrolystoho (Acer platanoides L.) [Screening and biological properties of TMV isolates (Tobamovirus) on plants of eastern plane (Platanus orientalis L.) and Norway maple (Acer platanoides L.)]. Agroecological journal, 4, 133-139 (in Ukrainian).

Peña, E. J., Heinlein, M., 2013. Cortical microtubuleassociated ER sites: organization centers of cell polarity and communication. Current Opinion in Plant Biology, 16, 764-773.

Romanchuk, S. M., 2010. Ultrastructure of statocytes and cells of the distal elongation zone in Arabidopsis thaliana under clinorotation. Cytology and Genetics, 44, 3-8.

Shevchenko, G. V., Kordyum, E. L., 2012. Ispolzovanie transgennyih rasteniy Arabidopsis thaliana-GFP-ABD2 v eksperimentah po izucheniyu tsitoskeleta $\mathrm{v}$ usloviyah modelirovannoy mikrogravitatsii [Application of transgenic Arabidopsis thaliana-GFP-ABD2 plants in experiments for the investigation of cytoskeleton in simulated microgravity]. Kosm. nauka tehnol., 18, 51-56 (in Russian).

Soga, K., Wakabayashi, K., Kamisaka, S., Hoson, T., 2006. Hypergravity induces reorientation of cortical microtubules and modifies growth anisotropy in azuki bean epicotyls. Planta, 224, 1485-1494.

Ueda, H., Yokota, E., Kutsuna, N., Shimada, T., Tamura, K., Shimmen, T., Hasezawac, S., Doljae, V. V., HaraNishimura, I. (2010). Myosin-dependent endoplasmic reticulum motility and $\mathrm{F}$-actin organization in plant cells. Proceedings of the National Academy of Sciences, 107, 6894-6899.

Van Gisbergen, P. A. C., Bezanilla, M., 2013. Plant formins: membrane anchors for actin polymerization. Trends in Cell Biology, 23, 227-233. 